SANTOS, ST; COSTA, JPBM; OLIVEIRA, FA; MARQUES, ICS; CORDEIRO, CJX; MORAIS NETA, HM. 2021. Calcium supplementation in nutrient solutions to mitigate salt stress in fertigated okra. Horticultura Brasileira 39: 324-329. DOI: http://dx.doi.org/10.1590/s0102-0536-20210313

\title{
Calcium supplementation in nutrient solutions to mitigate salt stress in fertigated okra
}

\author{
Sandy $T$ dos Santos ${ }^{1} \mathbb{D}$; Jessilanne Plinia BM Costa ${ }^{1} \mathbb{D}$; Francisco A Oliveira ${ }^{1} \mathbb{D}$; Isabelly CS Marques ${ }^{1} \mathbb{D}$; \\ Carla Jamile X Cordeiro ${ }^{1 \mathbb{D}}$; Helena M Morais Neta ${ }^{1 \mathbb{D}}$
}

${ }^{1}$ Universidade Federal Rural do Sermi-árido(UFERSA), Mossoró-RN, Brasil; sandy_thomaz@hotmail.com; jessilannyplinia@hotmail.com; thikaoamigao@ufersa.edu.br; isabelly_cristinna@hotmail.com; carlajamile0808@gmail.com; helena_morais13@hotmail.com

\begin{abstract}
The objective of this study was to evaluate the effect of calcium supplementation on saline water as a minimizing agent of saline stress in okra cultivars. The experiment was carried out in a greenhouse in Mossoró-RN using a completely randomized experimental design in a $2 \times 5$ factorial scheme with four replications. Two okra cultivars (Santa Cruz 47 and Valença) were tested fertigated with five fertigation managements $\left[\mathrm{F} 1=\right.$ irrigation with non-saline water $\left(0.5 \mathrm{dS} \mathrm{m}^{-1}\right)$ and fertigation with a standard dose of calcium $\left(4,733.8 \mathrm{mg} \mathrm{plant}^{-1}\right) ; \mathrm{F} 2$, $\mathrm{F} 3$, F4 and F5 = irrigation with saline water $\left(3.5 \mathrm{dS} \mathrm{m}^{-1}\right)$ and fertigation with increasing doses of calcium $(4,733.8 ; 7,100.7 ; 9,467.7$ and $11,834.5 \mathrm{mg}$ plant $^{-1}$, respectively)]. Plants were collected at 120 days after emergence and evaluated for growth variables (plant height, leaf number, stem diameter, leaf dry mass, stem, fruit and total) and yield (fruit number, average length of fruits, average diameter and yield). Cultivar Santa Cruz 47 presented the highest vegetative development but cultivar Valença was earlier and presented the largest number of harvests (19), allowing more harvested fruits (27 fruits per plant) and the highest yield $\left(659 \mathrm{~g} \mathrm{plant}^{-1}\right)$. The cultivars were not affected by the saline level and showed little response to extra calcium fertilization.
\end{abstract}

Keywords: Abelmoschus esculentus, salinity, fertigation management.

\section{RESUMO}

Suplementação com cálcio nas soluções nutritivas para mitigar o estresse salino no quiabeiro fertirrigado

Objetivou-se avaliar o efeito da suplementação cálcica em água salina como agente minimizador do estresse salino em cultivares de quiabeiro. $\mathrm{O}$ experimento foi desenvolvido em casa de vegetação, em Mossoró-RN utilizando o delineamento experimental inteiramente casualizado, em esquema fatorial $2 \times 5$, com quatro repetições. Foram testadas duas cultivares de quiabeiro (Santa Cruz 47 e Valença) fertirrigados com cinco manejos de fertirrigação [F1= irrigação com água não salina $\left(0,5 \mathrm{dS} \mathrm{m}^{-1}\right)$ e fertirrigação com dose padrão de cálcio $\left(4.733,8 \mathrm{mg}_{\text {planta }}{ }^{-1}\right) ; \mathrm{F} 2$, F3, F4 e F5= irrigação com água salina $\left(3,5 \mathrm{dS} \mathrm{m}^{-1}\right)$ e fertirrigações com dose crescentes de cálcio

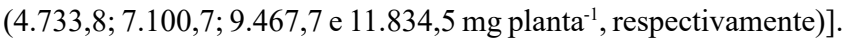
As plantas foram coletadas após 120 dias da emergência e avaliadas quanto aos fatores de crescimento (altura de plantas, número de folhas, diâmetro do caule, biomassa seca de folhas e biomassa seca de caule) e rendimento (número de frutos, comprimento médio de frutos, diâmetro médio e produção). A cultivar Santa Cruz 47 apresentou maior desenvolvimento vegetativo mas a cultivar Valença foi mais precoce e apresentou maior número de colheitas (19), possibilitando mais frutos colhidos (27 frutos por planta) e maior produção $(659 \mathrm{~g}$ planta $\left.^{-1}\right)$. As cultivares não foram afetadas pelo nível salino utilizado e apresentaram pouca resposta à adubação extra de cálcio.

Palavras-chave: Abelmoschus esculentus, salinidade, manejo da fertirrigação.

Received on August 26, 2020; accepted on July 5, 2021

$\mathrm{O}$ kra (Abelmoschus esculentus) is grown in several tropical, subtropical and temperate regions of the world, as its tolerance to hot weather, makes okra a versatile vegetable in relation to climatic adaptation. Okra fruits are rich in calcium, iron, vitamins $\mathrm{A}, \mathrm{B}$ and $\mathrm{C}$, in addition to being a good source of carbohydrates, proteins and minerals (Moraes et al., 2018; Santos et al., 2019). This crop is originated from Africa or India, being an annual vegetable belonging to Malvaceae family (Ferreira et al., 2012).

Okra production in Brazil was $128.460 \mathrm{t}$ in 2017 (IBGE, 2018), being the main producers the Northeast and Southeast regions; the state of São Paulo stands out as the largest producer, growing an area of 1.445 ha (IEA, 2021).

Okra demands too much water, so irrigation is very important (Ferreira et al., 2012). In the Brazilian Northeast, irrigation is essential for producing okra all year long; however, due to water limitation, the use of this input needs to be rational (Nascimento et al., 2017). Another limiting factor, besides the appropriate irrigation management, is the quality of irrigation water, especially in relation to dissolved salts concentration (Ferreira et al., 2012). The excess of dissolved salts, both in the soil solution and in the irrigation water, is one of the most serious problems faced by world agriculture, as it provides stress conditions and reduced productivity in most varied species of cultivated plants 
(Fernandes et al., 2010).

Salinity causes osmotic stress in plants, due to the imbalance of the osmotic potential between the soil and the plant. The ionic effect causes toxicity in the plant due to a high concentration of specific ions in soil and nutritional imbalance, due to the reduction in the uptake of essential elements for development (Munns \& Tester, 2008; Silva et al., 2013; Flowers et al., 2015). All these characteristics can result in a lower water uptake and, consequently, nutrient uptake too, causing a reduction in photosynthesis, growth, yield and fruit quality (Taiz et al., 2017; Modesto et al., 2019).

Growing more tolerant species is a good strategy for obtaining better plant development under high salinity conditions, concerning both soil and irrigation water. Okra has a salinity threshold limit of $1.3 \mathrm{dS} \mathrm{m}^{-1}$ (Maas, 1984); salinity tolerance depends on the genotypic variation among okra species, though (Haq et al., 2010).

Another strategy would be an appropriate mineral nutrition, considering that one of the negative effects of high saline levels on plants is nutritional imbalance. This imbalance is caused, mainly, by a greater sodium and chlorine accumulation in leaf tissues to the detriment of nutrient uptake such as calcium, due to the antagonistic effect between these nutrients (Marschner, 2012).

Calcium is an element that makes up the molecule of one or more organic compounds in the plant, such as cell wall calcium pectate (Faquin, 2005), being an important agent for maintaining the osmotic balance in plants (Lacerda et al., 2004). In addition, calcium can change the chemical quality of fruits (Korkmaz et al., 2017).

Studying other vegetables of this kind, several authors have been verifying that calcium supplementation in nutrient solution or foliar application was efficient to mitigate the deleterious effect of salinity on fruit yield and quality (Tantawy et al., 2014; Nizam et al., 2019).

Thus, the addition of extra calcium in waters with greater salinity can neutralize the negative effects of sodium on okra crop. The aim of this study was to evaluate the effect of calcium supplementation in saline water as an agent to minimize salt stress in okra cultivars.

\section{MATERIAL AND METHODS}

\section{Experimental area}

The experiment was carried out from November, 2017 to February, 2018, in a greenhouse in Centro de Ciências Agrárias (CCA), at Universidade Federal Rural do Semi-Árido (UFERSA),

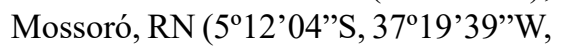
$18 \mathrm{~m}$ altitude). The greenhouse covered $126 \mathrm{~m}^{2}, 18-\mathrm{m}$ length, 7-m width, top cover of transparent low-density polyethylene film, transparent light diffuser (low density polyethylene film, LDPE), 150 microns thick and anti-UV additive.

\section{Experimental design}

The experiment was carried out in a completely randomized design, in a $2 \times 5$ factorial scheme, with four replicates. The experimental unit consisted of one 20-L pot, one plant per pot, totalizing 40 plants. The soil used was the Argisol, presenting the following chemical characteristics: $\mathrm{pH}=7.30 ; \mathrm{CE}_{(1.2 .5)}=0.41$ $\mathrm{dS} \mathrm{m} \mathrm{m}^{-1} \mathrm{MO}=3.31 ;\left(\mathrm{P}=1.9 ; \mathrm{K}^{+}=26.9\right.$; $\left.\mathrm{Na}^{+}=4.7 ; \mathrm{Ca}^{2+}=1.1\right) \mathrm{mg} \mathrm{dm}{ }^{-3} ;\left(\mathrm{Mg}^{2+}=\right.$ $0.7 ;(\mathrm{H}+\mathrm{Al})=1.49 ; \mathrm{SB}=1.89 ; \mathrm{t}=1.89$; $\mathrm{CTC}=3.37) \mathrm{cmolc} \mathrm{dm}^{-3} ; \mathrm{V}(\%)=56$; $\operatorname{PST}(\%)=1.21$.

\section{Treatments}

The treatments consisted of two okra cultivars (Santa Cruz 47 and Valença) using five fertigation managements, being one management without saline water $\left(0.5 \mathrm{dS} \mathrm{m}^{-1}\right)$ and the other treatments using saline water $(3.5 \mathrm{dS}$ $\mathrm{m}^{-1}$ ), according to Table 1 .

For a lower salinity (F1), we used water from a deep well located in UFERSA campus, showing the following chemical attributes: $\mathrm{pH}=8.30$; $\mathrm{CE}=0.50 \mathrm{dS} \mathrm{m}^{-1} ;\left(\mathrm{Ca}^{2+}=3.10 ; \mathrm{Mg}^{2+}=\right.$ $1.10 ; \mathrm{K}^{+}=0.30 ; \mathrm{Na}^{+}=2.30 ; \mathrm{Cl}^{-}=1.80$; $\mathrm{HCO}_{3}=3.00$ and $\left.\mathrm{CO}_{3}{ }^{2}=0.20\right) \mathrm{mmol}_{\mathrm{c}}$ $\mathrm{L}^{-1}$. To obtain the saline water $(3.5 \mathrm{dS}$ $\left.\mathrm{m}^{-1}\right)$, we used sodium chloride $(\mathrm{NaCl})$ dissolved in lower salinity water (F1). We adjusted salinity with the aid of a bench conductivity meter.

Five seeds were sown directly onto the soil, in each pot, at $2.0 \mathrm{~cm}$ depth. Seedlings were thinned 10 days after emergence (DAE), leaving just the most vigorous one in each pot. The pots were kept in the greenhouse, spacing $1.2 \mathrm{~m}$ between lines and $0.5 \mathrm{~m}$ between plants. From sowing to thinning, the pots were irrigated twice a day, in the morning and in the afternoon, using a fine-sived watering can.

The authors adopted the drip irrigation system previously evaluated under normal operating conditions. Microtube emitters, also called "spaghetti" tubes were used, internal diameter $1.5 \mathrm{~mm}$, length $0.5 \mathrm{~m}$, with $4.5 \mathrm{~L} \mathrm{~h}^{-1}$ average flow, with an emitter installed in each pot.

Two independent systems were installed, one for the lower salinity water (F1) and another for salinity waters (F2, F3, F4 and F5), using a circulating pump Metalcorte/Eberle, self-ventilated, model EBD250076, driven by a single-phase motor, $210 \mathrm{~V}$ voltage, $60 \mathrm{~Hz}$ frequency, a reservoir (310-L water tank), 16-mm-diameter hoses and microtubes.

Six daily irrigations were carried out, at 2-hour intervals, beginning at 7 a.m., for five minutes. During the experiment, each irrigation period became longer according to the plant development (Table 2).

Fertigations were done weekly, according to each treatment. The pace of macronutrient uptake of okra crop was used, obtained by Galati et al. (2013), with the following nutrient quantities: $\mathrm{N}=2,930.8 \mathrm{mg}_{\text {plant }}{ }^{-1} ; \mathrm{P}=$ 473.7 mg plant $^{-1} ; \mathrm{K}=6,002.8 \mathrm{mg}^{-1}$ plant $^{-1}$; $\mathrm{Ca}=4,733.8$ mg plant $^{-1} ; \mathrm{Mg}=1,196.3$ mg plant ${ }^{-1} ; \mathrm{S}=436.2 \mathrm{mg}$ plant $^{-1}$. Thus, according to the nutritive solutions, the following calcium quantities provided by calcium nitrate fertilizer were applied: $\mathrm{F} 1$ and $\mathrm{F} 2=4,733.8 \mathrm{mg}^{\text {plant }}{ }^{-1}$; $\mathrm{F} 3=7,100.7 \mathrm{mg}$ plant $^{-1} ; \mathrm{F} 4=9,467.7 \mathrm{mg}$ plant $^{-1} ; \mathrm{F} 5=11,834.5 \mathrm{mg} \mathrm{plant}^{-1}$.

During the experiment, phytosanitary control was carried out. We used the insecticide with active ingredient Imidacloprid $700 \mathrm{~g} \mathrm{~kg}^{-1}$, belonging to the chemical group Neonicotinoid, IV toxicology, at a dose of $20 \mathrm{~g} 100 \mathrm{~L}^{-1}$. 


\section{Studied factors}

At the end of the experiment (120 DAE) the plants were harvested and the following traits were evaluated: plant height $(\mathrm{PH})$, using a measuring tape graduated in $\mathrm{cm}$, measuring from substrate surface to the shoot tip; number of leaves (NL), counting all the leaves longer than $1.0 \mathrm{~cm}$; stem diameter (SD), measured with the aid of a digital caliper, $2.0 \mathrm{~cm}$ from the cutting site, considering the average of two measurements collected using the perpendicular positions; leaf dry mass (LDM) and stem dry mass (SDM), fruit dry mass (FDM) and total dry mass (TDM). To determine the dry mass, each part of the plant was dried in an oven at $65^{\circ} \mathrm{C}$, with forced air circulation until reaching constant mass. For yield, the fruits were harvested manually, as they reached a minimum 12-cm length, being still tender, without fibers, easily checked by breaking the tip of the fruit (ideal harvest point). Thus, the quantity of harvests differed between the cultivars, due to greater earliness of the cultivar Valença, being performed 19 and 8 harvests, considering the cultivars Valença and Santa Cruz 47, respectively.

In each harvest, the fruits were counted, obtaining the number of fruits (NF), which were evaluated for average length of fruits (LFR), using a ruler graduated in centimeters; average diameter of fruits (DFR), obtained using a digital caliper. Then, these fruits were weighed with a precision scale $(0.01 \mathrm{~g})$, obtaining the fresh mass and the fruit production (PROD).

\section{Statistical analysis}

Data were submitted to ShapiroWilk normality test and the variance analysis was performed using $\mathrm{F}$ test. The averages obtained in each treatment were compared among each other by Tukey test $(\mathrm{p}<0.05)$. The statistical analyses were carried out using Sisvar statistical software (Ferreira, 2014).

\section{RESULTS AND DISCUSSION}

\section{Development}

We found no significant difference for plant height $(\mathrm{PH})$ considering all the evaluated factors, including interaction between the factors. However, number of leaves (NL) and stem diameter (SD) were significantly affected $(\mathrm{p}<0.01)$ for the isolated cultivar factor, as well as the fruit dry mass (FDM) for fertigation (Table 3). No significant difference between cultivars was noticed, and also no significant difference for fertigations considering plant height $(\mathrm{PH})$ was noticed, obtaining an average of 146.4 $\mathrm{cm}$. For number of leaves (NL) and stem diameter (SD), the cultivar Santa Cruz 47 was superior to cultivar Valença on 94.88 and $31.09 \%$, respectively, but cultivar Valença was $41.2 \%$ superior, considering the fruit dry mass (FDM) (Table 3).

For the effect of fertigations on cultivars, the authors verified no significant response for $\mathrm{PH}, \mathrm{NL}, \mathrm{SD}$ and FDM, obtaining averages of 146.3 $\mathrm{cm}, 31.7$ leaves, $30.4 \mathrm{~mm}$ and $63.55 \mathrm{~g}$ plant $^{-1}$, respectively (Table 3 ).

These results corroborate, somehow, the results presented by Ferreira et al. (2012) and Nascimento et al. (2017). Evaluating the effect of saline stress on okra cultivar Santa Cruz 47, Ferreira et al. (2012) also observed no response to salinity for stem diameter and number of leaves. Plant height reduced when the plant was irrigated using more saline water. Nascimento et al. (2017) also verified that the number of flowers was not affected by salinity, although the height and diameter of the stem were reduced under higher salinities, which may be related to higher saline levels used. The values of the stem diameter did not change, probably, due to a higher accumulation of reserves in the plant stem in response to salinity (Ferreira et al., 2012).

Thus, no salinity effect (F2) on the evaluated variables was noticed in relation to the standard fertigation, with no $\mathrm{NaCl}$ addition (F1), showing that, concerning to these variables, the cultivars showed tolerance to the salinity used in this study $\left(3.5 \mathrm{dS} \mathrm{m}^{-1}\right)$. The tolerance of okra in relation to salinity depends on the genetic variation among the genotypes (Haq et al., 2010). This statement is completed by Ferreira et al. (2012) who state that the absence of salinity effect can be related to physiological traits related to the crop.

Evaluating the leaf dry mass (LDM) and stem dry mass (SDM), and total dry mass (TDM), the authors verified that the cultivars differed between each other in all fertigations, except for the standard fertigation (F1) (Figure 1). For LDM, cultivar Santa Cruz 47 was superior to Valença, 194.4; 84.5; 157.1 and $218.3 \%$, respectively, for fertigations F2, F3, F4 and F5 (Figure 1A). For MSC, Santa Cruz 47 was superior to Valença, 24.18; 194.4; 84.5; 157.1 and $218.0 \%$, in fertigations $\mathrm{F} 1$, F2 F3, F4, F5, respectively (Figure 1B). For TDM, no significant difference

Table 1. Description of fertigation applications in the experiment. Mossoró, UFERSA, 2018.

\begin{tabular}{|c|c|c|c|}
\hline $\begin{array}{l}\text { Fertigation } \\
\text { applications }\end{array}$ & 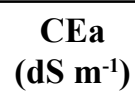 & $\begin{array}{c}\text { Ca doses } \\
\left(\text { mg plant }^{-1}\right)\end{array}$ & $\begin{array}{c}\text { Referential (Galati } \text { et } \\
\text { al., 2013) }\end{array}$ \\
\hline F1 & 0.50 & $4,733.8 *$ & $100 \%$ \\
\hline $\mathrm{F} 2$ & 3.50 & $4,733.8$ & $100 \%$ \\
\hline F3 & 3.50 & $7,100.7$ & $150 \%$ \\
\hline F4 & 3.50 & $9,467.7$ & $200 \%$ \\
\hline F5 & 3.50 & $11,834.5$ & $250 \%$ \\
\hline
\end{tabular}

Table 2. Detailing irrigation management and water applied in the experiment. Mossoró, UFERSA, 2018.

\begin{tabular}{lccc}
\hline \multirow{2}{*}{ Irrigation management } & \multicolumn{3}{c}{ Crop stages (days after emergence) } \\
\cline { 2 - 4 } & $\mathbf{0 - 4 0}$ & $\mathbf{4 1 - 8 0}$ & $\mathbf{8 1 - 1 2 0}$ \\
\hline Time per event (min) & 5 & 7 & 9 \\
Daily irrigation time (min) & 30 & 42 & 54 \\
Water applied daily (L plant & $-1)$ \\
$\begin{array}{l}\text { Water amount applied at different } \\
\text { development stages }\left(\mathrm{L} \mathrm{plant}^{-1}\right)\end{array}$ & 2.25 & 3.15 & 4.05 \\
\hline
\end{tabular}


Table 3. Average values of plant height (PH), number of leaves (NL), stem diameter (SD) and fruit dry mass (FDM) of two okra cultivars submitted to different doses of calcium applied via fertigation with saline water. Mossoró, UFERSA, 2018.

\begin{tabular}{lcccc}
\hline Cultivars & PH $(\mathbf{c m})$ & NL & SD $(\mathbf{m m})$ & FMD $\left(\mathbf{g ~ p l a n t}^{-1}\right)$ \\
\hline Valença & $143.15 \mathrm{a}$ & $21.50 \mathrm{~b}$ & $26.34 \mathrm{~b}$ & $74.4 \mathrm{a}$ \\
Santa Cruz 47 & $149.65 \mathrm{a}$ & $41.90 \mathrm{a}$ & $34.53 \mathrm{a}$ & $52.7 \mathrm{~b}$ \\
\hline Fertigation applications & & & & \\
\hline F1 & $157.75 \mathrm{a}$ & $26.75 \mathrm{a}$ & $30.15 \mathrm{a}$ & $54.7 \mathrm{a}$ \\
F2 & $143.00 \mathrm{a}$ & $29.62 \mathrm{a}$ & $29.37 \mathrm{a}$ & $72.3 \mathrm{a}$ \\
F3 & $145.12 \mathrm{a}$ & $32.00 \mathrm{a}$ & $30.78 \mathrm{a}$ & $60.1 \mathrm{a}$ \\
F4 & $147.87 \mathrm{a}$ & $33.87 \mathrm{a}$ & $30.10 \mathrm{a}$ & $66.7 \mathrm{a}$ \\
F5 & $137.75 \mathrm{a}$ & $36.25 \mathrm{a}$ & $31.77 \mathrm{a}$ & $63.9 \mathrm{a}$ \\
\hline Cultivar (C) & $\mathrm{ns}$ & $* *$ & $* *$ & $* *$ \\
Fertigation (F) & $\mathrm{ns}$ & $\mathrm{ns}$ & $\mathrm{ns}$ & $\mathrm{ns}$ \\
C x F & $\mathrm{ns}$ & $\mathrm{ns}$ & $\mathrm{ns}$ & $\mathrm{ns}$ \\
CV (\%) & 11.91 & 23.93 & 8.42 & 27.96 \\
\hline
\end{tabular}

$\mathrm{ns} ;{ }^{* *}=$ non-significant and significant at $1 \%$, respectively. ${ }^{*} \mathrm{~F} 1=$ irrigation with no-saline water $\left(0.5 \mathrm{dS} \mathrm{m} \mathrm{m}^{-1}\right)$ and fertigation with standard dose of calcium $\left(4,733.8 \mathrm{mg} \mathrm{plant}^{-1}\right) ; \mathrm{F} 2, \mathrm{~F} 3, \mathrm{~F} 4$ and F5 = irrigation with saline water $\left(3.5 \mathrm{dS} \mathrm{m}^{-1}\right)$ and fertigation applications with increasing doses of calcium (4,733.8; 7,100.7; 9,467.7 and 11,834.5 $\mathrm{mg} \mathrm{plant}^{-1}$, respectively). Average values followed by the same letter, in the columns, do not differ among each other by Tukey test $(\mathrm{p}<0.05)$.

Table 4. Values of average length of fruit (LFR), diameter of fruit (DFR), number of fruits (NFR), fruit production (PROD) of two okra cultivars submitted to different doses of calcium applied via fertigation with saline water. Mossoró, UFERSA, 2018.

\begin{tabular}{lllll}
\hline Cultivars & LFR $(\mathbf{c m})$ & DFR $(\mathbf{c m})$ & NFR & PROD $\left(\mathbf{g ~ p l a n t}^{-1}\right)$ \\
\hline Valença & $16.94 \mathrm{a}$ & $1.88 \mathrm{a}$ & $27.10 \mathrm{a}$ & $659.23 \mathrm{a}$ \\
Santa Cruz 47 & $16.12 \mathrm{a}$ & $1.87 \mathrm{a}$ & $19.85 \mathrm{~b}$ & $496.75 \mathrm{~b}$ \\
\hline Fertigation & & & & \\
\hline F1 & & $1.86 \mathrm{a}$ & $20.62 \mathrm{a}$ & $553.61 \mathrm{a}$ \\
F2 & $16.91 \mathrm{a}$ & $1.89 \mathrm{a}$ & $25.50 \mathrm{a}$ & $620.91 \mathrm{a}$ \\
F3 & $16.17 \mathrm{a}$ & $1.84 \mathrm{a}$ & $24.12 \mathrm{a}$ & $550.91 \mathrm{a}$ \\
F4 & $16.39 \mathrm{a}$ & $1.90 \mathrm{a}$ & $23.87 \mathrm{a}$ & $593.22 \mathrm{a}$ \\
F5 & $16.62 \mathrm{a}$ & $1.88 \mathrm{a}$ & $23.25 \mathrm{a}$ & $571.27 \mathrm{a}$ \\
\hline Cultivar (C) & $16.57 \mathrm{a}$ & $\mathrm{ns}$ & $* *$ & $* *$ \\
Fertigation (F) & $\mathrm{ns}$ & $\mathrm{ns}$ & $\mathrm{ns}$ & $\mathrm{ns}$ \\
C x F & $\mathrm{ns}$ & $\mathrm{ns}$ & $\mathrm{ns}$ & $\mathrm{ns}$ \\
CV (\%) & $\mathrm{ns}$ & 7,12 & 23,63 & 19,16 \\
\hline
\end{tabular}

$\mathrm{ns} ;{ }^{* *}=$ non-significant and significant at $1 \%$, respectively. ${ }^{*} \mathrm{~F} 1=$ irrigation with no-saline water $\left(0.5 \mathrm{dS} \mathrm{m}^{-1}\right)$ and fertigation with standard dose of calcium $\left(4,733.8 \mathrm{mg} \mathrm{plant}^{-1}\right) ; \mathrm{F} 2, \mathrm{~F} 3, \mathrm{~F} 4$ and F5= irrigation with saline water $\left(3.5 \mathrm{dS} \mathrm{m}^{-1}\right)$ and fertigation applications with increasing doses of calcium $\left(4,733.8 ; 7,100.7 ; 9,467.7\right.$ and $11,834.5 \mathrm{mg} \mathrm{plant}^{-1}$, respectively). Average values followed by the same letter, in the columns, do not differ among each other by Tukey test $(\mathrm{p}<0.05)$.

between the cultivars in fertigation F1 was noticed; nevertheless, cultivar Santa Cruz 47 was superior, 97.0; 46.7; 96.8 and $107.8 \%$, in fertigations F2, F3, F4 and F5, respectively (Figure 1C).

In relation to fertigation effect, the authors observed that for the three variables (LDM, SDM and TDM), the only significant response was for cultivar Santa Cruz 47. LDM increased $39.9 \mathrm{~g}$ plant $^{-1}(73.45 \%)$ in fertigation F4 in relation to $\mathrm{F} 1$. We also noticed that when saline fertigation with no extra $\mathrm{Ca}(\mathrm{F} 2)$ was used MSF increased 30.9 g plant $^{-1}$ (56.97\%), comparing to the standard fertigation F1 (Figure 1A). For SDM, we observed similar behavior, with an increase of $95.7 \mathrm{~g} \mathrm{plant}^{-1}(73.43 \%)$ in fertigation $\mathrm{F} 4$, in relation to $\mathrm{F} 1$. Comparing the fertigation without $\mathrm{Ca}$ (F2) with standard fertigation (F1), the authors observed an increase of $74.2 \mathrm{~g}$ plant $^{-1}(56.96 \%)$ (Figure 1B). For TDM, we also verified that the highest values were obtained with the use of saline fertigation, regardless of the addition of extra $\mathrm{Ca}$. We verified an increase of 160.2 g plant $^{-1}(71.8 \%)$ in TDM in F4 in relation to $\mathrm{F} 1$ and $130.35 \mathrm{~g} \mathrm{plant}^{-1}$ $(58.43 \%)$ in treatment 2 compared to the standard treatment (F1) (Figure 1C).

Evaluating the variables LDM, SDM and TDM together, we verified a 
similar behavior between them, with a positive response for the cultivar Santa Cruz 47 to the addition of $\mathrm{NaCl}$ in fertigation solution and no response to $\mathrm{Ca}$ application. These results suggested that the saline level used was not sufficient to cause saline stress to plants, although it was higher than the salinity threshold for the crop $\left(1.3 \mathrm{dS} \mathrm{m}^{-1}\right)$ (Maas, 1984). For the cultivar Valença,

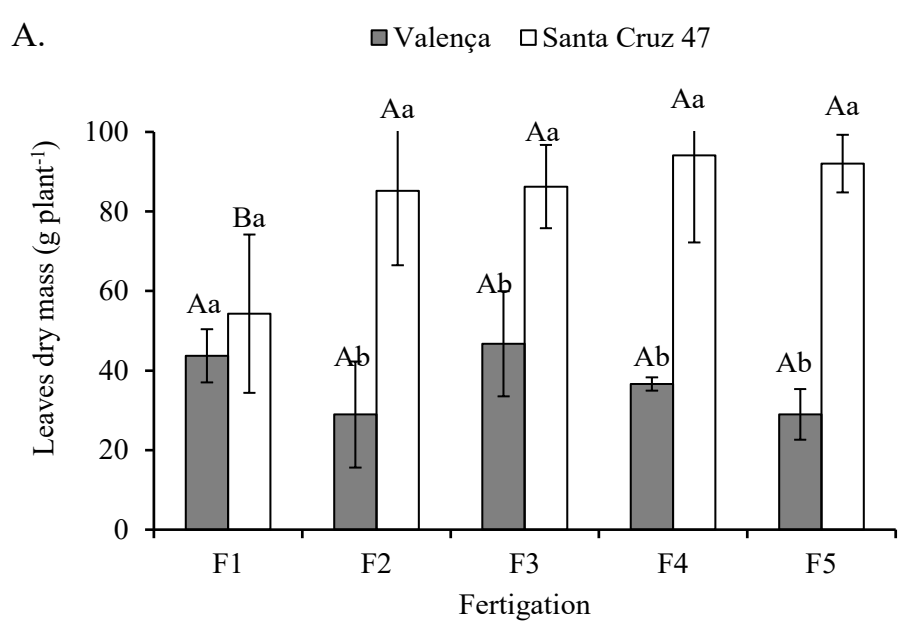

B.

$\square$ Valença $\square$ Santa Cruz 47

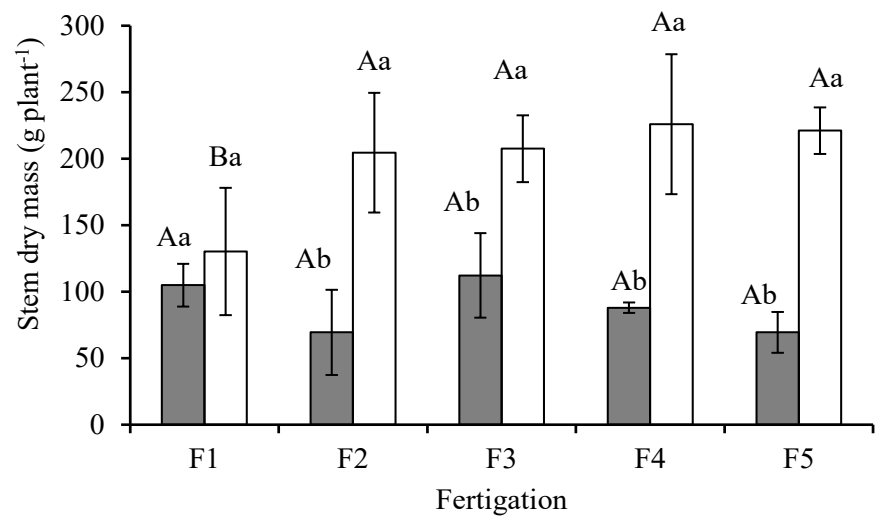

C.

口Valença $\square$ Santa Cruz 47

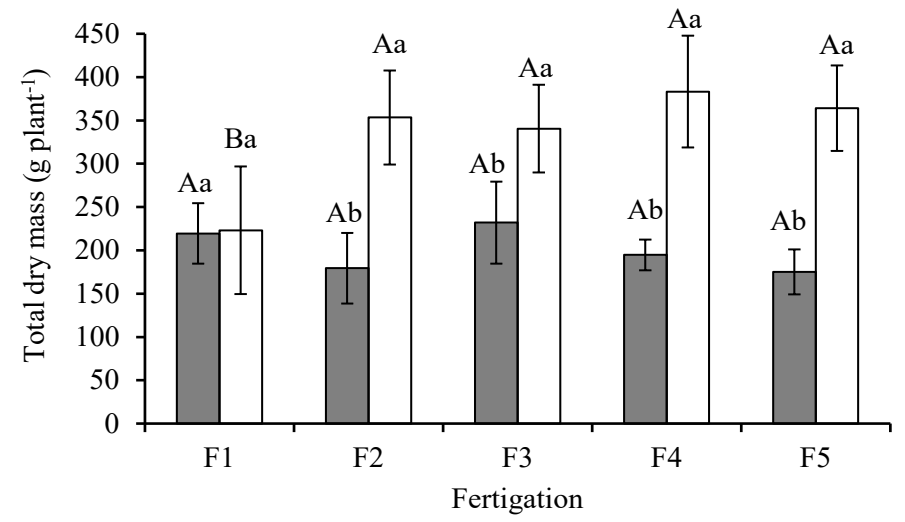

Figure 1. Leaf dry mass (A), stem dry mass (B) and total dry mass (C) in okra cultivars submitted to different doses of calcium applied via fertigation with saline water. F1= irrigation with non-saline water $\left(0.5 \mathrm{dS} \mathrm{m}^{-1}\right)$ and fertigation with standard dose of calcium $(4,733.8$ mg plant $\left.{ }^{-1}\right) ; \mathrm{F} 2, \mathrm{~F} 3, \mathrm{~F} 4$ and $\mathrm{F} 5=$ irrigation with saline water $\left(3.5 \mathrm{dS} \mathrm{m}^{-1}\right)$ and fertigation applications with increasing doses of calcium $(4,733.8 ; 7,100.7 ; 9,467.7$ and $11,834.5 \mathrm{mg}$ plant $^{-1}$, respectively). ns; ${ }^{* *}=$ non-significant and significant at $1 \%$, respectively. Mossoró, UFERSA, 2018.

no effect of fertigation was observed, regardless of the addition of extra calcium. Besides, the fact that cultivar Santa Cruz 47 showed to be superior to cultivar Valença at higher doses of calcium, it may indicate that this cultivar is more demanding considering this nutrient.

Several authors reported a decrease in dry masses of leaves and stem in okra plants grown under saline stress (Ünlükara et al., 2008; Nascimento et al., 2017; Modesto et al., 2019). The differences related to the results obtained in this study comparing with the ones found in literature can be explained, partly, due to the genetic variability and to growing conditions, as in protected cultivation the plants show a lower water requirement.

In relation to extra $\mathrm{Ca}$ supplementation (F3, F4 and F5), no effect on any cultivar was observed, comparing with saline treatment (F2), differing from the results obtained by Nizam et al. (2019), working with other fruit vegetables. Calcium supplementation did not affect any of the cultivars, maybe because of the high sodium concentration, which inhibited calcium uptake due to the antagonistic effect between these elements (Marschner, 2012).

\section{Yield}

The variance analysis did not show any significant response for interaction between cultivar factors and fertigation, not even for the isolated factor fertigation concerning average length of fruits (LFR), average diameter of fruit (DFR), number of fruits (NFR) and production (PROD). However, we verified a significant response for the isolated factor cultivar for NFR and PROD $(p<0.01)$, not being verified significant response for the other variables (Table 4).

Cultivar Valença was superior to cultivar Santa Cruz 47 for NFR and PROD in 36.52 and $32.71 \%$, respectively. No difference between cultivars, considering LFR and DFR was verified. These variables showed average values of $16.53 \mathrm{~cm}$ for LFR and $1.87 \mathrm{~cm}$ for DFR (Table 4).

The superiority of the cultivar Valença is related to a higher number 
of harvested fruits, considering that no variation between the cultivars for fruit size (LFR and DFR) was observed. This can be explained by the fact that Valença is an earlier cultivar comparing with cultivar Santa Cruz 47, providing higher number of harvests. The fact that okra harvest is performed according to the size of fruit (ideal harvest point) explains the absence of significant difference between the cultivars for LFR and DFR. Harvesting okra every two days is the best way to obtain fruit at the ideal harvest point (Oliveira et al., 2007).

In relation to effect of fertigation, according to what was previously mentioned, no significant effect on any variables was noticed. The experiment showed averages of $16.53 \mathrm{~cm}$ for fruits average length; $1.89 \mathrm{~cm}$ for average fruit diameter; 23.5 fruits per plant and production of $577.98 \mathrm{~g} \mathrm{plant}^{-1}$ (Table 4).

Similar results were reported by Ferreira et al. (2012), showing that the saline level in irrigation water $(2.5 \mathrm{dS}$ $\mathrm{m}^{-1}$ ) did not affect the number of fruits and production of grains of okra cultivar Santa Cruz 47. Nevertheless, the use of water with electrical conductivity above the threshold salinity recommended for okra $\left(1.3 \mathrm{dS} \mathrm{m}^{-1}\right)$ results in a reduction in crop yield (Elshaikh et al., 2017; Modesto et al., 2019).

Higher salinity stress tolerance in okra has been observed in some other studies. Modesto et al. (2019) obtained threshold salinity of $5.43 \mathrm{dS} \mathrm{m}^{-1}$ in hydroponic system and Ünlükara et al. (2008) obtained $3.48 \mathrm{dS} \mathrm{m}^{-1}$ growing okra in soil conditioned in pots in protected cultivation, implying that genetic material and growing system change the response of okra to salinity. According to Ferreira et al. (2012), tolerance to salinity is related to several genes, as it could also be influenced by factors related to interaction between the environment, development and plant physiology.

No effect of saline water on okra was observed. This fact may be related to the high frequency irrigation adopted in this experiment, since as the soil moisturize is kept close to field crop evapotranspiration is favored, consequently reducing the effects of salinity on biochemical and physiological processes, which would directly result in losses in development and yield (Ljubojevi et al., 2017).

In general, the salinity used in this experiment was not enough to cause saline stress on plants, probably due to the irrigation management adopted, it means, high irrigation frequency.

Thus, the authors concluded that an extra calcium application did not improve the development and yield of okra irrigated with saline water. The cultivar Valença was the most productive as it is an earlier cultivar, providing a greater number of harvests, being recommended to be grown in regions where water shows saline level up to $3.5 \mathrm{dS} \mathrm{m}^{-1}$.

\section{REFERENCES}

ELSHAIKH, N; ALI, A; AGBNA, G; BASHEER, A. 2017. Interaction among groundwater quality, soil properties and okra crop productivity. Agricultural and Environmental Sciences Journal 1: 7-14.

FAQUIN, V. 2005. Nutrição mineral de plantas. Lavras: Universidade Federal de Lavras, 186p.

FERNANDES, OB; PEREIRA, FHF; ANDRADE JÚNIOR, WP; QUEIROGA, RCF; QUEIROGA, FM. 2010. Efeito do nitrato de cálcio na redução do estresse salino no meloeiro. Revista Caatinga 23: 93-103.

FERREIRA, DF. 2014. Sisvar: a guide for its bootstrap procedures in multiple comparisons. Ciência e Agrotecnologia 38: 109-112.

FERREIRA, LE; MEDEIROS, JF; SILVA, NKC; LINHARES, PSF; ALVES, RDC. 2012. Salinidade e seu efeito sobre a produção de grãos do quiabeiro Santa Cruz 47. Revista Verde 7: 108-113.

FLOWERS, TJ; MUNNS, R; COLMER, TD. 2015. Sodium chloride toxicity and the cellular basis of salt tolerance in halophytes. Annals of Botany 115: 419-431.

GALATI, VC; CECÍLIO FILHO, AB; GALATI, VC; ALVES, AU. 2013. Crescimento e acúmulo de nutrientes da cultura do quiabeiro. Semina: Ciências Agrárias 34: 191-200.

HAQ, I; KHAN, AA; AZHAR, FM; ULLAH, E. 2010. Genetic basis of variation for salinity tolerance in okra (Abelmoschus esculentus L.). Pakistan Journal of Botany 42: 1567-1581.

IBGE - Instituto Brasileiro de Geografia e Estatística. 2018. Censo Agropecuário 2017 - Brasil. Available at https://sidra.ibge.gov. br/tabela/6619\#resultado

IEA - Instituto de Economia Agrícola. 2021. Banco de Dados: Estatística de Produção Paulista. Available at $<$ http://ciagri.iea.sp.gov.br/ nia1/subjetiva.aspx?cod_sis $=1 \&$ idioma $=1>$. Accessed July 05, 2021.

KORKMAZ, A; KARAGÖL, A; AKINOĞLU,
G. 2017. The effects of $\mathrm{CaCl}_{2}$ on fruit yield, quality and nutrient contents of tomato under $\mathrm{NaCl}$ stress conditions. Eurasian Journal of Soil Science 6: 84-91.

LACERDA, CD; CAMBRAIA, J; OLIVA, MA; RUIZ, HA. 2004. Influência do cálcio sobre o crescimento e solutos em plântulas de sorgo estressadas com cloreto de sódio. Revista Brasileira de Ciência do Solo 28: 289-295.

L JUB O JEVI, M; O GN JANOV, V; MAKSIMOVIC, I; CUKANOVIC, J; DULIC, J; SZABO, Z; SZABO, S. 2017. Effects of hydrogel on growth and visual damage of ornamental salvia species exposed to salinity. Clean - Soil, Air, Water 45: 1-8.

MAAS, EU. 1984. Crop tolerance. California Agriculture 38: 20-1.

MARSCHNER, P. 2012. Marschner's mineral nutrition of higher plants. $3^{\text {rd }}$ ed. New York: Academic Press, 651p.

MODESTO, FJN; SANTOS, MACM; SOARES, TM; SANTOS, EPM. 2019. Crescimento, produção e consumo hídrico do quiabeiro submetido à salinidade em condições hidropônicas. Irriga 24: 86-97.

MORAES, ER; REIS, AC; SILVA, NEP; FERREIRA, M; MENEZES, FG. 2018. Nutrientes no solo e produção de quiabo conforme doses de silicato de cálcio e magnésio. Revista de Agricultura Neotropical 5: 60-65.

MUNNS, R; TESTER, M. 2008. Mechanisms of salinity tolerance. Plant Biologic 59: 651-681.

NASCIMENTO, PS; PAZ, VPS; FRAGA JÚNIOR, LS; COSTA, IP. 2017. Crescimento vegetativo do quiabeiro em função da salinidade da água de irrigação e da adubação nitrogenada. Colloquium Agrariae 13: 10-15.

NIZAM, R; HOSAIN, MT; HOSSAIN, ME; ISLAM, MM; HAQUE, MA. 2019. Salt stress mitigation by calcium nitrate in tomato plant. Asian Journal of Medical and Biological Research 5: 87-93.

SANTOS, HC; PEREIRA, EM; MEDEIROS, RL; COSTA, PMDA; PEREIRA, WE. 2019. Produção e qualidade de quiabo produzido com adubação mineral e orgânica. Revista Brasileira de Engenharia Agrícola e Ambiental 23: 97-102.

SILVA, AO; KLAR, AE; SILVA, EFF; TANAKA, AA; JUNIOR, JFS. 2013. Relações hídricas em cultivares de beterraba em diferentes níveis de salinidade do solo. Revista Brasileira de Engenharia Agricola e Ambiental 17: 11431151.

TAIZ, L; ZEIGER, E; MØLLER, IM; MURPHY, A. 2017. Fisiologia e Desenvolvimento Vegetal. $6^{\mathrm{a}}$ ed. Porto Alegre: Artmed, 858p.

TANTAWY, AS; SALAMA, YAM; ABDELMAWGOUD, MR; GHONAME, AA. 2014. Comparison of chelated calcium with nano calcium on alleviation of salinity negative effects on tomato plants. Middle East Journal of Agriculture Research 3: 912-916.

ÜNLÜKARA, A; KURUNÇ, A; KESMEZ, GD; YURTSEVEN, E. 2008. Growth and evapotranspiration of okra (Abelmoschus esculentus L.) as influenced by salinity of irrigation water. Journal of Irrigation and Drainage Engineering 134: 160-166. 